\title{
The Making of the African American Population: The Economic Status of the Ex-Slave and Freedmen Population in Post-Civil War America, 1860 - 1920
}

\author{
by Richard R. Verdugo*
}

\begin{abstract}
The end of the Civil War, the 1863 Emancipation Proclamation, and the 13th Amendment to the US Constitution ended slavery as an institution in the US. For years slavery divided the country, North and South. With the end of slavery, it was expected that slaves, as freed men and women, would be able to improve their economic status, moving freely and pursuing jobs in which they could earn a decent living. But there were forces at work in the South that made it impossible to find decent employment, and the first Great Migration of the Black population began between 1910 and 1930. Nevertheless, Blacks began leaving the South (especially the Deep South) earlier. In this paper I follow the occupational careers of several age-cohorts of former Black slaves and free Blacks using the 1870 - 1920 census data.
\end{abstract}

Results from my analysis point out that the Black population, comprising a combination of former slaves and free Black persons, experienced some upward mobility, but only if they moved north. Living in the South shortly after the Civil War and into the latter part of the 19th century did not bode well economically for the Black population.

\section{Introduction}

Slavery was a divisive institution in America. The North was on the cusp of industrializing, whereas the Southern economy was based on plantation agriculture and slave labour. The "peculiar" institution ended as a consequence of the CivilWar, the Emancipation Proclamation, and the 13th Amendment to the US Constitution. The effect on the slave population, theoretically, should have been economically positive.

The end of slavery freed former slaves from an institution that dictated just about every aspect of their lives. After the end of slavery, ex-slaves had the opportunity to pursue jobs of their own choosing and improve their economic status. However, there were forces at work that created barriers for the economic progress of the African American population following the Civil War: the rise of violent, racist organizations, such as the KKK; the ability of White Southerners to retake control of the South; and the fact that former slaves were slow in leaving the South, which lay in ruins.

But not all African Americans were slaves, some were actually Freedmen and women and their status might have allowed them to improve their Human Capital and economic status once slavery had been abolished. Before the Civil War, as Freedmen, they could pursue businesses, own land, and some owned slaves of their own. Other factors also helped them improve their economic status compared to their slave counterparts, such as being literate and in better health [slavery was an institution that taxed the health status of slaves (Steckel 1986a, b, c, 2004). For example, some scholars have noted that slaves were shorter than Whites and free African Americans (Carson 2009)]. These and other factors were important in determining the future economic status of the African American population. But the defining factor was the end of slavery, which allowed former slaves the freedom to pursue work so they could support themselves and their families. How did former slaves fare over time? Did they improve their economic status? How did they compare to their free, Black counterparts? 
The purpose of my paper is to examine the economic status of the African American population after the Civil War. ${ }^{1}$ I compare and contrast the economic status of former slaves with African Americans who were Freedmen during slavery. Data for my analysis are from the 1860 Census Slave Population Database and from the 1870 - 1920 Census. The historical events of the Civil War and its aftermath created a social structure that affected the economic status of both ex-slaves and Freedmen. Moreover, this social structure created barriers for the upward mobility of African Americans, and placed them at a very low position in such a social structure, and their upward social mobility has been excessively slow and sometimes completely blocked. In other words, a rather complex structure of inequality was created after slavery ended compared to the very clearly defined system during slavery.

\section{Background}

The entire period from the origins of slavery, slavery as a caste-like system, the Civil War, Reconstruction, and afterwards, is a tale of the emergence and demise of slavery as a stratification system that did not coincide with a stratification system emerging in the North, which was based on an emerging meritocracy and a Capitalist mode of production. The Civil War ended the slave system and the South, initially devastated by the war, re-emerged as Southern Conservatives took back their privileges through political re-alliance and violence. As Whites took back the South and introduced a different kind of race-based stratification system, African Americans began migrating North; first slowly, and then in great numbers between 1910 and 1940. In essence there were two factors that drove the first Great Migration: the racial climate in the South that was racist and violent; and the lack of jobs because the South had been completely devastated by the War (Wilkerson 2010).

The demise of slavery and the movement of ex-slaves out of the Deep South and to the North raise two questions:

- Compared to African Americans who were free before the Civil War, did the socioeconomic status of ex-slaves improve after the Civil War and into the early part of the 2oth Century? Some scholars have noted that ex-slaves may have been in poorer health than free Blacks, and these health concerns may have affected them and their children's ability to acquire Human Capital and thus improve their socioeconomic status (Fogel 1994; Case et al 2002; Steckel 2004; Costa 2005; Case and Paxson 2006; Costa et al 2007).

- Did movement out of the Deep South improve the economic status of ex-slaves and Freedmen? There were many reasons to leave the South after the civil war. To begin with, as I have pointed out, the South was devastated by the war and the lack of infrastructure affected the ability to find or decent paying work (Goldin 1979; Margo 2004). And the violence in the South against Blacks was another factor. ${ }^{2}$

\section{Analytic Strategy}

My strategy is to provide descriptive and multivariate analyses on the economic status of both the ex-slave and Freedmen from 1870 to 1920. As such, I look at two measures of economic status: the Duncan SEl scores and at an eight (8) occupational categorical scheme. I also control for literacy, gender, migration, and age cohort.

\section{Methods}

\section{A. Data}

\section{The 1860 Slave Sample}

The Public Use Micro data Samples of the Slave Population are a series of six samples taken from the 1850 and 1860 Censuses of Slave Inhabitants. In both 1850 and 1860, the United States census 
contained two population schedules. Schedule 1 enumerated details of the free population, while Schedule 2 enumerated details of the slave population. Samples from Schedule 1 of the 1850 and 1860 censuses are available at the main IPUMS website. The Slave PUMS provides the first nationallyrepresentative samples of Schedule 2, the Census of Slave Inhabitants, as well as the first nationallyrepresentative sample linking data from the Slave Schedules to data from the Free Population Schedules.

The questions included in the Census of Slave inhabitants were relatively few: schedules from both years asked slaves' age, sex, colour, and disabilities including whether they were deaf, dumb, blind, insane or idiotic. Enumerators were allowed to record slaves' names in the 1860 census if the slave was over 100 years of age. Slaveholders also provided information about the number of slaves who had been manumitted or who had escaped in the prior year. In 1860, the number of houses provided to slaves on the slaveholding was also tallied.

\section{The 1860 to 1920 Census Samples}

a. 1860: 1-in-100 national random sample of the free population. African American slaves are not included in this dataset. Individual-level data on the 1860 slave population is available at the $1850-60$ Slave PUMS website.

b. 1870: 1-in-100 national random sample of the population with a 1-in-50 over-sample of the African American population. This is a weighted sample.

c. 1880: 1-in-100 national random sample of the population.

d. 1900: 1-in-100 national random sample of the population, including Alaskans, Hawaiians, and American Indians.

e. 1910: 1-in-100 national random sample of the population, including Alaskans, Hawaiians, and American Indians.

f. 1920: 1-in-100 national random sample of the population, including Alaskans, Hawaiians, and American Indians.

\section{B. Variables}

Table 1 presents the variables used in my analysis and their operationalization. 


\begin{tabular}{|c|c|}
\hline Variable Name & Operationalization \\
\hline Socioeconomic Index, SEI & Duncan Score \\
\hline Slave status & $\begin{array}{l}\text { Slave status is determined by two variables. First if the respondent } \\
\text { was born before } 1865 \text {. Second, if the respondent was born in a slave } \\
\text { owning State. The slave owning states are Alabama, Mississippi, } \\
\text { Georgia, South Carolina, North Carolina, Texas, Florida, Virginia, } \\
\text { Arkansas, Tennessee, and Louisiana. }\end{array}$ \\
\hline Migration & $\begin{array}{l}\text { The difference between where a respondent was born and their } \\
\text { residence at the time ofthe Census interview. There are four categories } \\
\text { of migration status: } \\
\text { (1) Born in the South/Lives in the South = SS } \\
\text { (2) Born in the South/Lives in the North = SN } \\
\text { (3) Born in the North/Lives in the North = NN } \\
\text { (4) Born in the North/Lives in the South = NS } \\
\text { In computing these categories, I computed dummy variables for Born } \\
\text { in the South and Lives in the South - Born in the South (BS) = 1, o = } \\
\text { otherwise. Lives in the South (LS) = } 1 \text {, o = otherwise. } \\
\text { I then used Boolean logic by the following equation: } \\
\text { Migration }=(B S * 2) 2+\text { LS. The equation gives me the four categories. }\end{array}$ \\
\hline Literacy & $\begin{array}{l}\text { Four dummy variables: } L_{1}=\text { can read and write, } L_{2}=\text { can read, but not } \\
\text { write, } L_{3}=\text { can write, but not read, } L_{4} \text { (benchmark) = cannot read or } \\
\text { write }\end{array}$ \\
\hline Gender, Male & A dummy variable, $1=$ Male, $0=$ Otherwise \\
\hline Age Cohorts & $\begin{array}{l}\text { A series of dummy variables: } \\
\text { Ac1 }=10<20 \\
A C 2=20<30 \\
\text { Ac3 }=30<40 \\
A C 4=40<50 \\
A C 5=50<60 \\
\text { Ac6 }=60+\text { (benchmark in multivariate analyses) }\end{array}$ \\
\hline Jobs & $\begin{array}{l}\text { A series of dummy variables: } \\
\mathrm{J}_{1}=\text { professional white collar (benchmark in multivariate analyses) } \\
\mathrm{J}_{2}=\text { Farm } \\
\mathrm{J}_{3}=\text { Manager } \\
\mathrm{J}_{4}=\text { Agent } \\
\mathrm{J}_{5}=\text { Seller } \\
\mathrm{J}_{6}=\text { Craftsman } \\
\mathrm{J}_{7}=\text { Blue Collar, skilled } \\
\mathrm{J}_{8}=\text { Labor }\end{array}$ \\
\hline
\end{tabular}


I should point out that I limit my labour market analysis to persons age $16+$ in the labour force (ILF) in 1870; age 26+ and ILF in 1880; age 46+ and ILF in 1900; age 56+ and ILF in 1910; and age 66+ and ILF in 1920. I have used these age limits due to the aging of the slave cohort.

\section{Findings}

\section{A. The Black Population: $1860-1920$}

The Black population increased in size from 1860 to 1920 (see Figure 1 below). In 1860, which includes the slave population, the Black population stood at approximately 4.4 million. By 1920 it had grown to 10.5 million. Of this number, the proportion that was composed of former slaves declined significantly. In 1860, nearly 90 percent of the Black population was slaves (89.2 percent). In 1920, slightly more than 6 percent were former slaves, as the vast majority of the slave cohort died off. Table 2 presents descriptive statistics for this section. The data compare former slaves with Freedmen from 1860 to 1920.

Figure 1: The Black and Slave Population: $1790-1860$

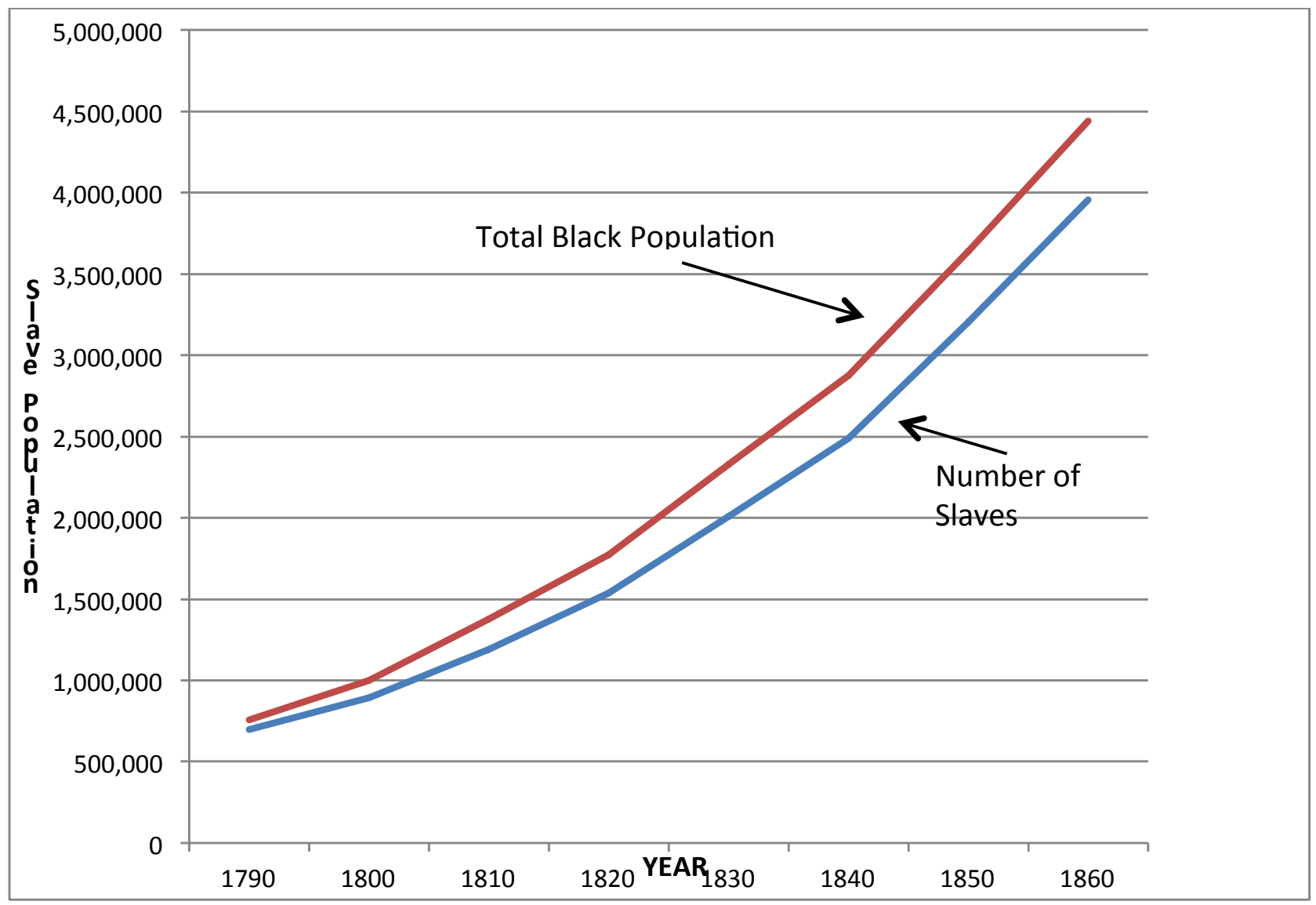




\begin{tabular}{|c|c|c|c|c|c|c|}
\hline \multirow{2}{*}{$\begin{array}{l}\text { Indic a tor / } \\
\text { Slave Status }\end{array}$} & \multicolumn{6}{|c|}{ Year } \\
\hline & 1860 & 1870 & 1880 & 1900 & 1910 & 1920 \\
\hline \multicolumn{7}{|l|}{ Former slaves } \\
\hline $\begin{array}{l}\text { Percent of } \\
\text { total }^{\text {a }}\end{array}$ & 89.2 & 77.24 & 50.64 & 20.94 & 12.21 & 6.17 \\
\hline \multicolumn{7}{|l|}{ Migration: ${ }^{\mathrm{b}}$} \\
\hline \multicolumn{7}{|l|}{ NN } \\
\hline \multicolumn{7}{|l|}{ NS } \\
\hline SN & & 4.17 & 4.92 & 7.53 & 7.96 & 8.59 \\
\hline SS & & 95.83 & 95.08 & 92.47 & 92.04 & 91.41 \\
\hline \multicolumn{7}{|l|}{ Literacy: ${ }^{b}$} \\
\hline Write/Read & & 13.56 & 25.80 & 33.28 & 37.89 & 40.65 \\
\hline Nt Write/Read & & 4.76 & 7.09 & 6.08 & 5.96 & 3.65 \\
\hline Write/Nt Read & & 0.11 & 0.02 & 0.21 & 0.00 & 0.00 \\
\hline $\begin{array}{l}\text { Nt Write/Nt } \\
\text { Read }\end{array}$ & & 81.57 & 67.08 & 60.49 & 56.05 & 55.50 \\
\hline $\begin{array}{l}\text { Gender } \\
\text { (Males): }\end{array}$ & 50.30 & 68.14 & 67.94 & 72.09 & 66.97 & 74.64 \\
\hline \multicolumn{7}{|l|}{ Cohorts: $^{\mathrm{b}}$} \\
\hline $0<10$ & 31.7 & & & & & \\
\hline $10<20$ & 25.2 & 16.02 & 15.17 & & & \\
\hline $20<30$ & 17.7 & 33.02 & 34.11 & & & \\
\hline $30<40$ & 11.0 & 19.44 & 19.69 & 16.65 & & \\
\hline $40<50$ & 7.1 & 14.93 & 13.69 & 37.19 & 20.54 & \\
\hline $50<60$ & 3.8 & 9.61 & 9.46 & 26.00 & 45.44 & 25.39 \\
\hline $60+$ & 3.4 & 6.98 & 7.87 & 20.16 & 34.02 & 74.61 \\
\hline
\end{tabular}




\begin{tabular}{|c|c|c|c|c|c|c|}
\hline \multirow{2}{*}{$\begin{array}{c}\text { Indicator/ } \\
\text { Slave Status }\end{array}$} & \multicolumn{6}{|c|}{ Year } \\
\hline & 1860 & 1870 & 1880 & 1900 & 1910 & 1920 \\
\hline \multicolumn{7}{|l|}{ Freedmen } \\
\hline \multicolumn{7}{|l|}{ Migration: $^{a}$} \\
\hline NN & & 93.51 & 92.86 & 90.25 & 90.41 & 91.17 \\
\hline NS & & 6.49 & 7.14 & 9.75 & 9.59 & 8.83 \\
\hline \multicolumn{7}{|l|}{ SN } \\
\hline \multicolumn{7}{|l|}{ SS } \\
\hline \multicolumn{7}{|l|}{ Literacy: ${ }^{\mathrm{b}}$} \\
\hline Write/Read & & 73.84 & 78.20 & 80.72 & 84.20 & 87.13 \\
\hline $\begin{array}{c}\text { Nt Write/ } \\
\text { Read }\end{array}$ & & 4.76 & 7.09 & 6.08 & 4.03 & 3.65 \\
\hline $\begin{array}{c}\text { Write/Nt } \\
\text { Read }\end{array}$ & & 0.11 & 0.02 & 0.21 & 0.00 & 0.00 \\
\hline $\begin{array}{c}\text { Nt Write/Nt } \\
\text { Read }\end{array}$ & & 18.86 & 16.95 & 14.83 & 11.77 & 9.31 \\
\hline $\begin{array}{l}\text { Gender } \\
\text { (Males): }\end{array}$ & 46.8 & 75.44 & 72.46 & $75 \cdot 5^{8}$ & 65.35 & 67.96 \\
\hline \multicolumn{7}{|l|}{ Cohorts: $^{b}$} \\
\hline $0<10$ & 25.6 & & & & & \\
\hline $10<20$ & 23.6 & 14.91 & 16.15 & & & \\
\hline $20<30$ & 17.7 & 33.20 & 33.26 & & & \\
\hline $30<40$ & 12.6 & 22.97 & 22.41 & 20.90 & & \\
\hline $40<50$ & 8.9 & 13.97 & 12.71 & 37.14 & $25 \cdot 37$ & \\
\hline $50<60$ & 6.2 & 8.19 & 8.55 & 28.46 & 48.94 & 32.61 \\
\hline $60+$ & $5 \cdot 5$ & 6.76 & 6.92 & 13.50 & 25.69 & 67.39 \\
\hline \multicolumn{7}{|c|}{ a Data in this line refer to all Blacks and are not limited to labor force participation. } \\
\hline $\mathrm{b}$ Those in the labo & & & & & & \\
\hline
\end{tabular}




\section{Slaves and Freedmen: $1860-1920$}

These data are presented in several ways. In one data stream, I compare all free Blacks and all former slaves; in another stream, I compare free Blacks and former slaves controlling for age and labour market participation; and finally, I compare all free Blacks in the labour market to former slaves in the labour market. These data streams are presented in Table 2.

a. Migration: Movement from the South to the North was slow. In 1870, about 4.2 percent of the exslave population moved to the North, and by 1920 the percentage who had migrated from the South to the North grew to 8.6 percent.

Among Freedmen, there was not movement from the South to the North in 1870, and the same nonmovement in 1920. However, there was movement from the North to the South among Freedmen: in $1870,6.5$ percent, and 8.8 percent in 1920.

b. Literacy: Among ex-slaves there were some dramatic increases in literacy between 1870 and 1920. In 1870 about 13.6 percent of ex-slaves were literate and by 1920 the percentage jumped to 40.7 .

Among Freedmen, the percentage who indicated they were literate was 74 and in 1920 this increased to 87 percent.

c. Gender: Among ex-slaves, in 1860, about 50 percent of those in the labour force were males and by 192074.6 percent.

Among Freedmen, the same pattern is observed, but in 1860 the percentage of males in the labour force was 46.8 percent. And by 1920 this increased to 67.9 percent.

d. Cohorts: I limited the age of Freedmen to the age of ex-slaves in the sample in order to make reasonable comparisons.

Compared to Freedmen, ex-slaves appeared to be slightly younger. And over time, a greater proportion of ex-slaves than Freedmen reached old age. For example, among ex-slaves in 1870, fully 57 percent were under age 20, while 49 percent of Freedmen were under age 20 . By 192074.6 percent of ex-slaves were age $60+$, and 67.4 percent of Freedmen had reached this age. Note though, that in 1920, the age restriction among Freedmen is $66+$ because I needed to equalize both ex-slaves and Freedmen on age. So, the data for Freedmen represent those age 66 and older.

\section{Socioeconomic Status: 1870 - 1920}

Table 3 presents data on the socioeconomic status of former slaves and freedman from 1870 to 1900. 


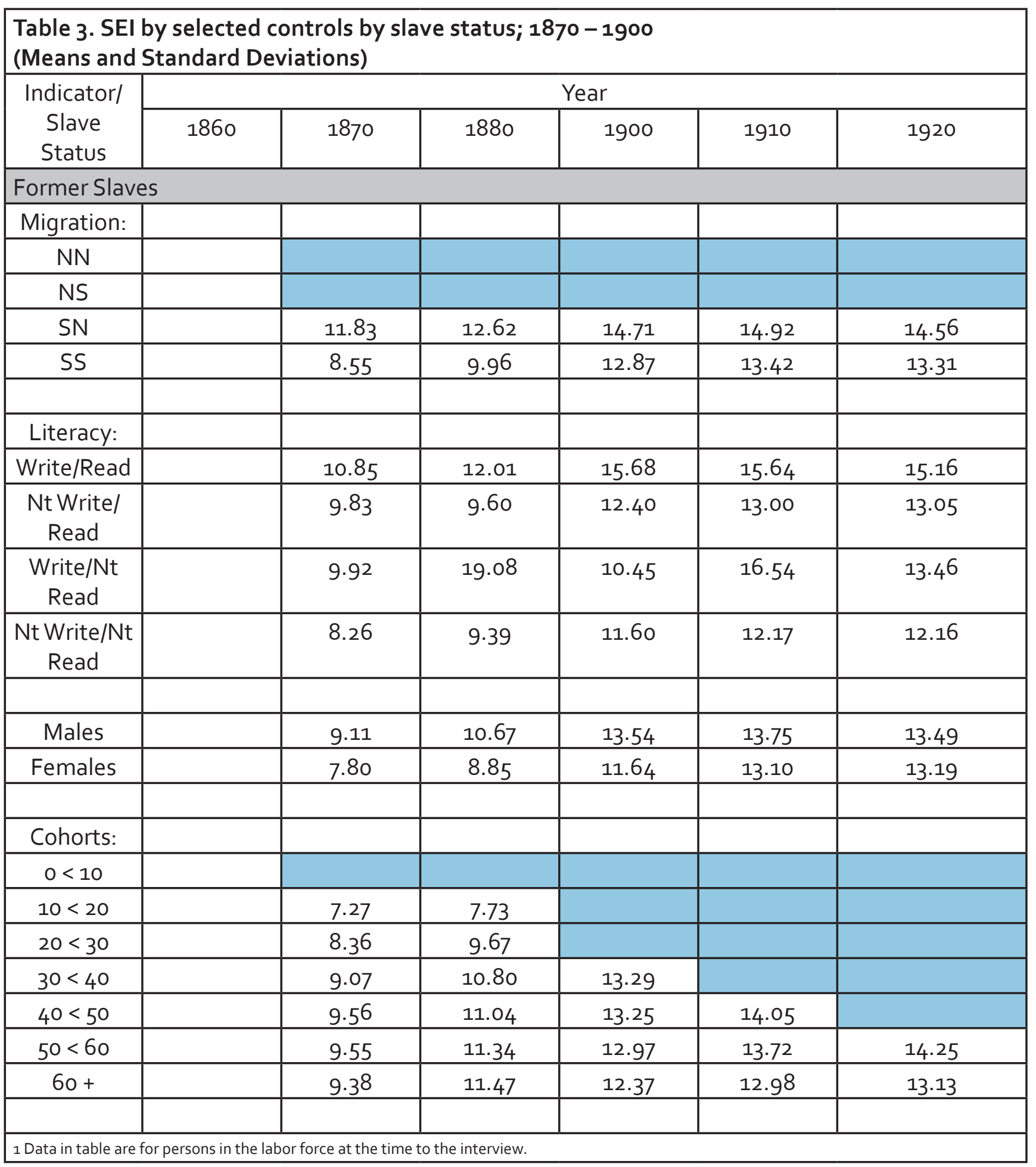




\begin{tabular}{|c|c|c|c|c|c|c|}
\hline \multirow{2}{*}{$\begin{array}{c}\text { Indicator/ } \\
\text { Slave Status }\end{array}$} & \multicolumn{6}{|c|}{ Year } \\
\hline & 1860 & 1870 & 1880 & 1900 & 1910 & 1920 \\
\hline \multicolumn{7}{|l|}{ Freedmen } \\
\hline & & & & & & \\
\hline \multicolumn{7}{|l|}{ Migration: $^{\text {a }}$} \\
\hline NN & & 11.08 & 12.49 & 14.50 & 16.96 & 17.38 \\
\hline NS & & 12.97 & $19 \cdot 36$ & 16.83 & 20.44 & 10.73 \\
\hline \multicolumn{7}{|l|}{ SN } \\
\hline \multicolumn{7}{|l|}{ SS } \\
\hline \multicolumn{7}{|l|}{ Literacy: } \\
\hline Write/Read & & 12.01 & 13.79 & 15.79 & 18.26 & 17.49 \\
\hline $\begin{array}{l}\text { Nt Write/ } \\
\text { Read }\end{array}$ & & 10.32 & 10.06 & 9.27 & 10.46 & 9.09 \\
\hline $\begin{array}{c}\text { Write/Nt } \\
\text { Read }\end{array}$ & & & & 12.00 & & \\
\hline $\begin{array}{c}\text { Nt Write/Nt } \\
\text { Read }\end{array}$ & & 8.40 & 10.12 & 10.51 & 12.76 & 13.24 \\
\hline Males & & 11.37 & 13.49 & 15.03 & 18.23 & 17.59 \\
\hline Females & & 10.70 & 11.67 & 13.77 & $15 \cdot 55$ & 15.11 \\
\hline \multicolumn{7}{|l|}{ Cohorts: } \\
\hline \multicolumn{7}{|l|}{$0<10$} \\
\hline $10<20$ & & 9.87 & 10.53 & & & \\
\hline $20<30$ & & 11.01 & 12.04 & & & \\
\hline $30<40$ & & 11.50 & 17.08 & 15.35 & & \\
\hline $40<50$ & & 11.47 & 13.12 & 13.30 & 17.75 & \\
\hline $50<60$ & & 11.45 & 11.60 & 15.98 & 17.22 & 19.36 \\
\hline $60+$ & & 12.36 & 11.44 & 15.03 & 16.99 & $15 \cdot 55$ \\
\hline 0 & & & & & & \\
\hline
\end{tabular}


a. Migration: Migration has an important effect on the socioeconomic status of both Freedmen and ex-slaves. For ex-slaves, moving from the South to the North appears to have positive effects on their socioeconomic status. Thus, in 1870 , ex-slaves that moved from the South to the North had higher SEI scores than ex-slaves who stayed in the South: 11.83 v. 8.55. While the SEI gap narrowed by 1920, ex-slaves who had moved to the North still had higher SEl scores: 14.56 v. 13.31.

Among Freedmen, migration had an effect on their SEI scores. From 1870 to 1910, Freedmen who migrated from the North to the South had higher SEI scores than those who remained in the North. However, by 1920 the trend changed and those in the North had higher SEI scores.

In terms of comparisons between ex-slaves and Freedmen, it appears that for ex-slaves migrating (from the South to the North) lead to a significant improvement in the SEI scores; whereas, among Freedmen, migrating, between 1870 and 1920, appears to have had some negative effects on their SEI score. In fact, in 1920, among Freedmen, of the same age as ex-slaves, who migrated from the North to the South, their SEI scores declined from nearly 13 in 1870 to 11 percent. In contrast, those who did not migrate at all, either from North/South or South/North, effects were positive, but slightly more for Freedmen. Generally, residing in the North had better SEl effects for both Freedmen and ex-slaves.

b. Literacy: Literacy has a significant effect on the socioeconomic status of both Freedmen and exslaves. Among ex-slaves, those who were literate (they could read and write) saw a near 5 point increase in their SEI scores from 1870 to 1920. In addition, literate ex-slaves had higher SEI scores than those who were illiterate (they could read/not write, or not read/write).

Among Freedmen, those that were literate also had a socioeconomic advantage. Thus, among literate Freedmen, their socioeconomic status increased from 12 in 1870 to about 17.5 in 1920 . Illiterate Freedmen and ex-slaves, however, also saw an increase in their socioeconomic status between 1870 and 1920. Among Freedmen, the increase was from 8.4 in 1870 to 13.2 in 1920; among ex-slaves the increase was from 8.3 to 12.2 .

c. Gender: The effect of gender on socioeconomic status varied by slave status. Among ex-slaves, males had higher SEI scores throughout the period under study, but the SEI gap narrowed so that by 1920 the SEI scores between males and females was nearly equal. For example, the gender-based SEI gap in 1870 was 1.31, and by 1920 it was .30.

Among Freedmen, in contrast to ex-slaves, males had higher SEl scores throughout the 1870 to 1920 period. In 1870 the gender SEI gap was .67, and by 1920 it had increased to 2.48 points on the SEI index. It also appears that Freedmen, both males and females, had higher SEI scores than ex-slaves.

d. Cohorts: The SEI scores among Freedmen were greater than those of ex-slaves throughout $1870-$ 1920, regardless of cohort status.

We can gain a sharper picture of SEI differences by looking at zero-order correlations between SEI and the variables discussed above.

Figures 2-4 display correlations between SEI and migration, literacy, and gender (males).

The variables discussed above. 
Figure 2

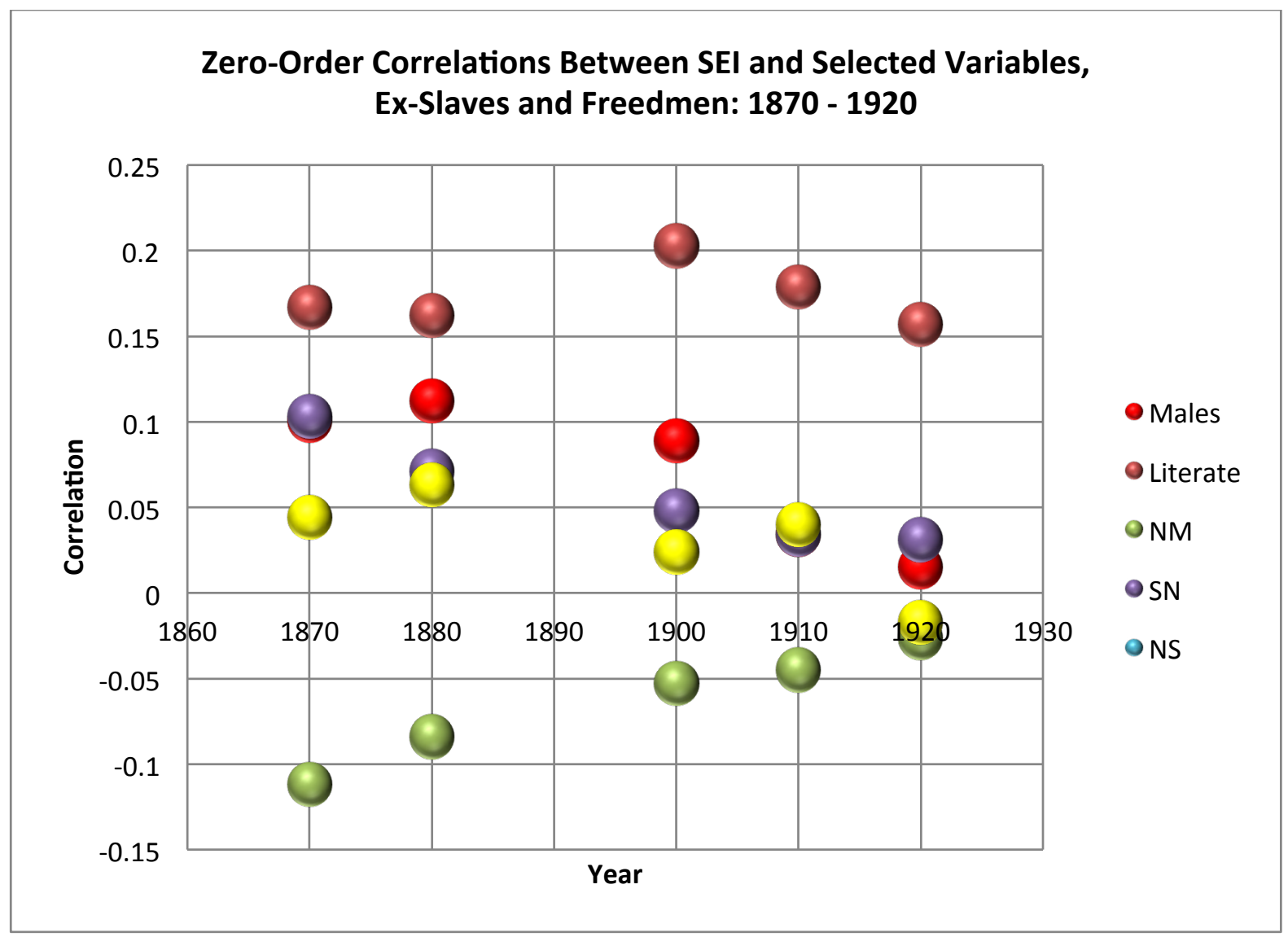

Figure 3

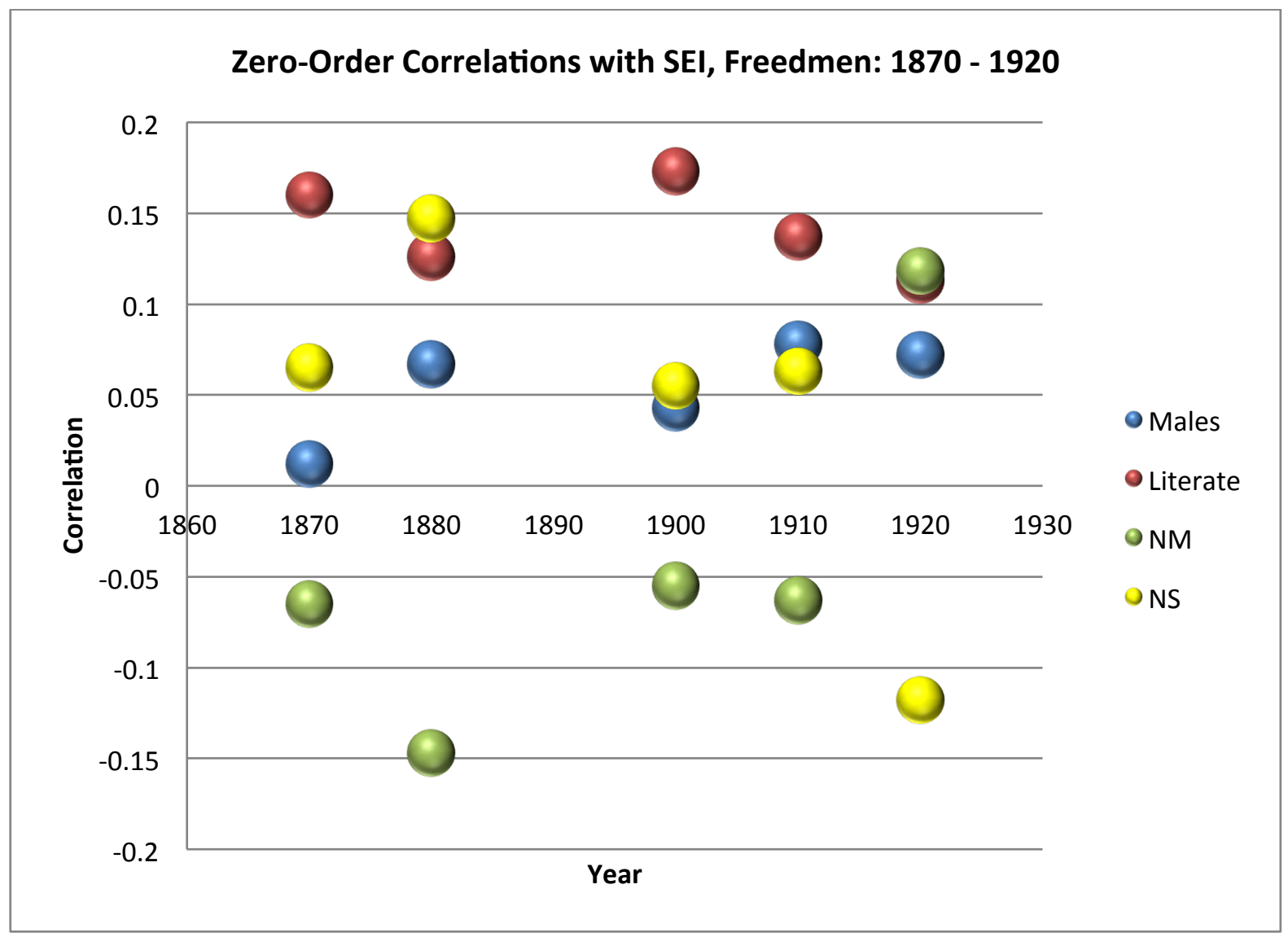


Figure 4

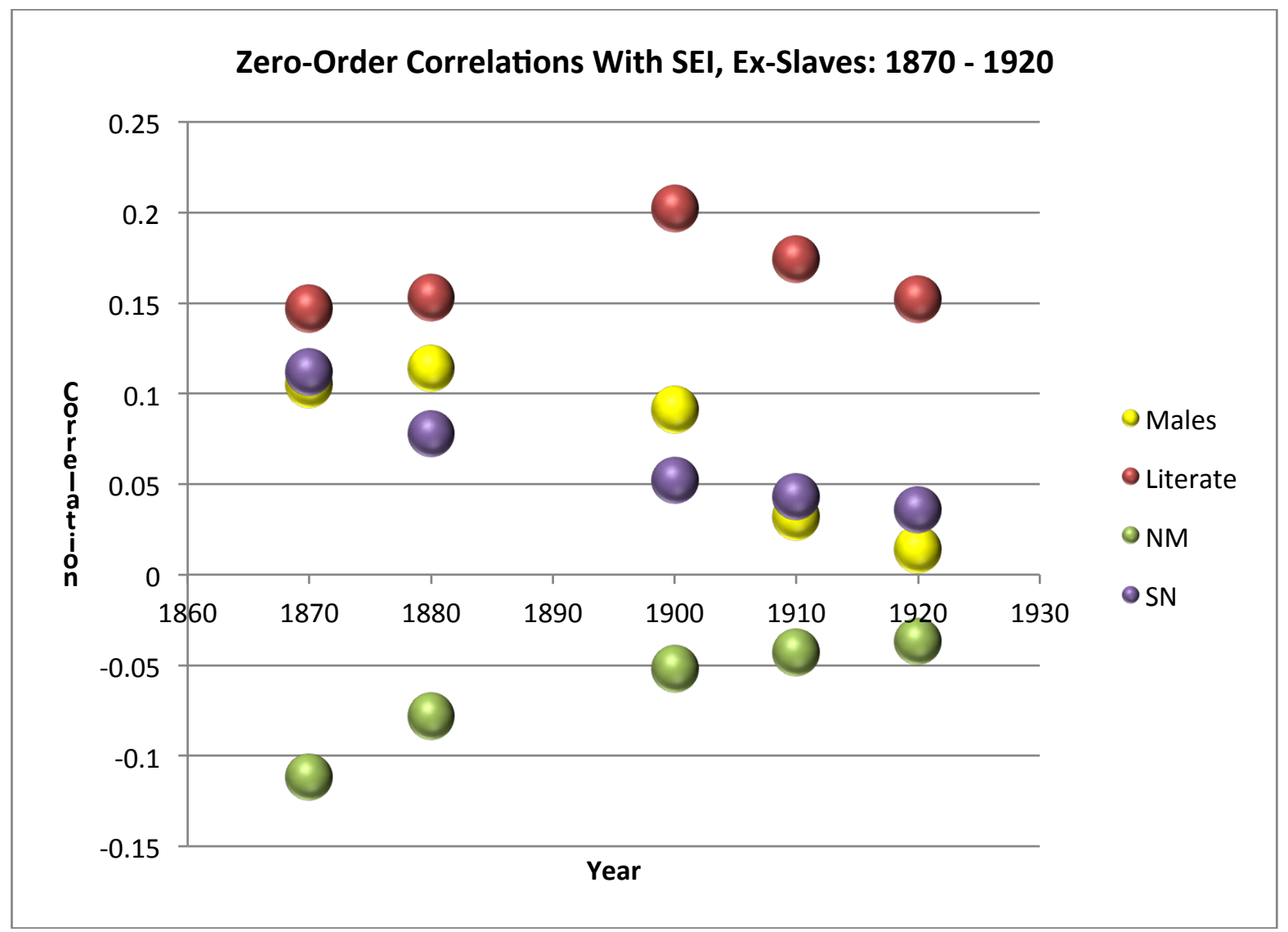

The correlations between our selected variables and the SES index are not large, in any year. However, results are fairly interesting. Looking at the correlations among both Freedmen and ex-slaves (Figure 2 above), indicates that literacy is related to SEI, more so than any other variable. Never the less, only one variable, no migration, seems to show an upward swing over time; all other variables show declines from 1870 to 1920.

In terms of Freedmen alone, literacy exhibits the highest association with the SEI index from 1870 to 1910 , but not in 1920. In 1920 it appears that Freedmen who did not migrate (stayed in either the South or North) had higher SEI scores than those migrating to the South from the North.

The patterns observed for the total sample and for Freedmen are also displayed among ex-slaves. Literacy shows the highest correlation with the SEl, those not migrating exhibit an upward swing in their association with the SEI, and all other items show a downward swing in their association with the SEI.

\section{Jobs: $1870-1920$}

Figure 5 displays the occupational distribution of both ex-slaves and Freedmen. We see movement into better jobs over time for both groups.

Ex-slave status has an effect on jobs. For Freedmen, the movement has been into professional and farm-related occupations. Thus, in 1870 about 4.5 percent of Freedmen were located in both these occupations. By 1920, the percent of Freedmen in both occupations increased to 14 percent. Among 


\section{Figure 5}

\section{Occupational Distribution, Freedmen and Ex-Slaves: 1870-1920}

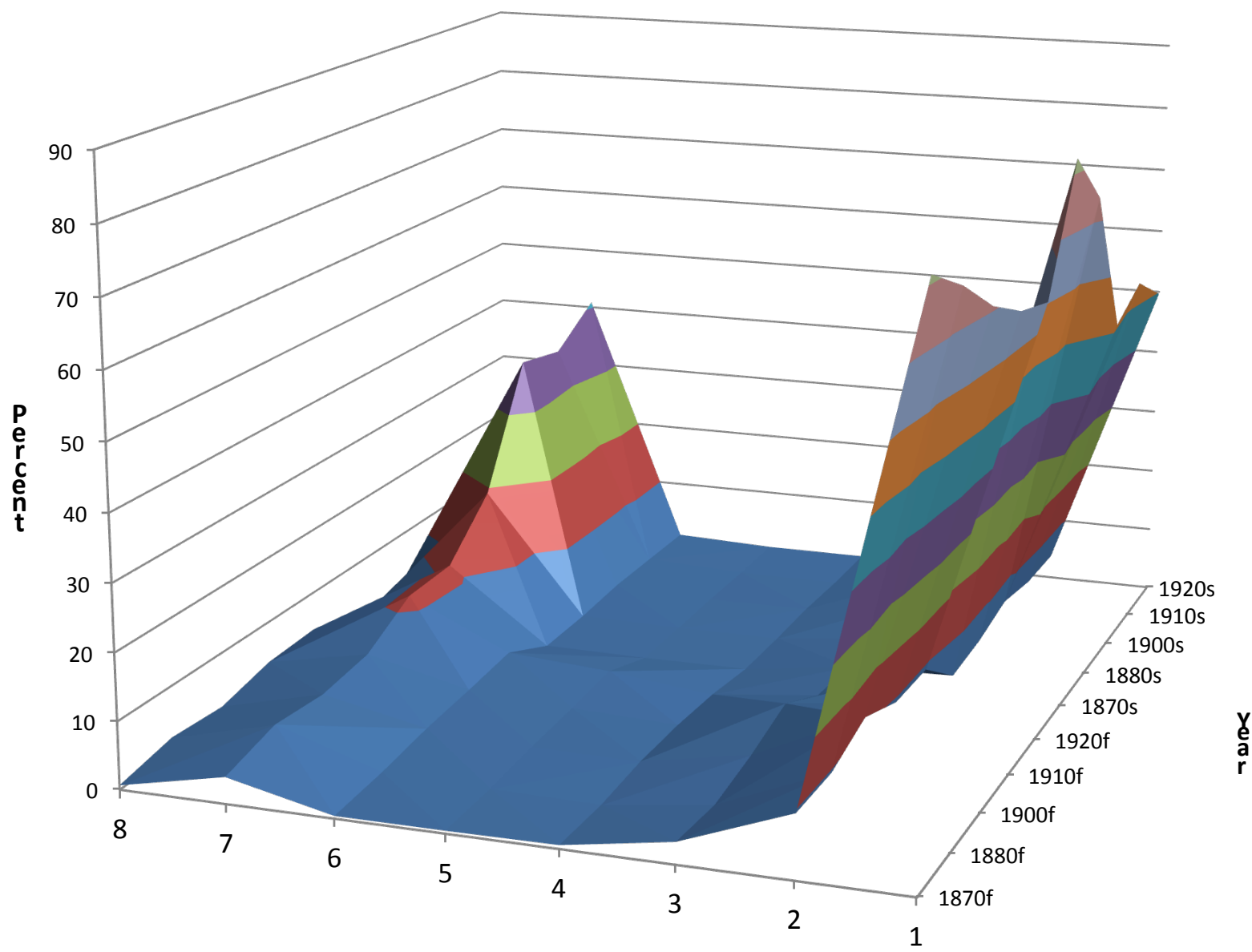

Occupation

ex-slaves, the vast majority of the movement has been into farm occupations. In 1870, 11.7 percent of ex-slaves were in farm occupations. By 1920 the percent increased to about 40 percent.

What is also interesting is that the largest percent of both Freedmen and ex-slaves can be found in labour jobs. However, in 1920 less than half of ex-slaves were to be found in labour jobs; but about two-thirds of Freedmen were in labour jobs.

\section{B. Multivariate Analysis: 1870 - 1920}

Table 4 presents regression models for the years 1870 to $1920^{4}$. The regressions model SEI as a function of selected predictors. Each model has a Deviation of about 1 (scaled deviation value/degrees of freedom), and LLs that indicate a good fit. 


\begin{tabular}{|c|c|c|c|c|c|c|c|c|c|c|}
\hline & 1870 & & 1880 & & 1900 & & 1910 & & 1920 & \\
\hline Predictors & $B$ & P-Value & $B$ & P-Value & $B$ & P-Value & $B$ & P-Value & $B$ & P-Value \\
\hline Intercept & 1.95 & $\begin{array}{c}< \\
0.0001\end{array}$ & 1.947 & $<.0001$ & 2.279 & $<.0001$ & 2.613 & $<.0001$ & 2.865 & $<.0001$ \\
\hline Slave & -0.096 & $\begin{array}{c}< \\
0.0001\end{array}$ & -0.085 & $<.0001$ & 0.031 & 0.2018 & -0.107 & 0.0004 & -0.1585 & 0.0002 \\
\hline Male & 0.111 & $\begin{array}{c}<< \\
0.0001\end{array}$ & 0.139 & $<.0001$ & 0.01 & $<.0001$ & 0.00001 & 0.9942 & -0.008 & 0.6613 \\
\hline Age & 0.005 & $\begin{array}{c}< \\
0.0001\end{array}$ & 0.008 & $<.0001$ & 0.002 & 0.0007 & 0 & 0.9718 & -0.003 & 0.007 \\
\hline SN & 0.212 & $\begin{array}{c}<< \\
0.0001\end{array}$ & 0.115 & $<.0001$ & 0.031 & 0.0794 & 0.105 & 0.4431 & 0.013 & 0.6503 \\
\hline NS & 0.204 & $\begin{array}{c}<< \\
0.0003\end{array}$ & 0.44 & $<.0001$ & 0.166 & 0.0275 & 0.229 & 0.0161 & -0.436 & 0.002 \\
\hline Literate & 0.245 & $\begin{array}{c}< \\
0.0001\end{array}$ & 0.265 & $<.0001$ & 0.291 & $<.0001$ & 0.245 & $<.0001$ & 0.208 & $<.0001$ \\
\hline Scale & 0.052 & & 0.045 & & 0.039 & & 0.039 & & 0.038 & \\
\hline $\mathrm{LL}$ & -46764.72 & & -68006.5 & & -41714.6 & & -30408.4 & & -13985.7 & \\
\hline Deviance & 1.033 & & 1.038 & & 1.045 & & 1.043 & & 1.046 & \\
\hline
\end{tabular}

There are five interesting stories to be generated from this table. To begin with, ex-slaves tend to have lower SEI scores than Freedmen. The only exception occurs in 1900 when there is no distinction in SEI scores between ex-slaves and Freedmen.

Second, males have higher SEI scores than females from 1870 to 1900 . But in 1910 and 1920 , there does not appear to be a difference in the SEl scores between males and females.

Third, older workers (age) appear to have higher SEI scores than younger workers, from about 1870 to 1900. But in 1910 age has no effect, and in 1920 older workers have lower SEl scores than workers at the lower end of the age distribution.

Fourth, from 1870 to 1900 , migrating from the South to the North increases one's SEI score. But in 1910 and 1920 such migration has no effect compared to those who have not migrated at all. Also, migrating from the North to the South has greater effects on SEI than non-migration throughout the 1870 to 1920 period. However, in 1920 the North to South migrants had lower SEI scores than those who did not migrate at all. Finally, does South to North or North to South migration have greater SEI advantage? Generally, and contrary to what I had expected, South to North migration, net of other items in the model, does not appear to have a consistent advantage. Indeed, it appears that North to South migration is more likely to be advantageous. This latter result is most likely because Freedmen have taken this route and they have more Human Capital, such as being literate.

Finally, literacy matters. Literacy is associated with higher SEI scores throughout the $1870-1920$ period. 


\section{Conclusion}

Slavery divided America, North and South, and created many social, economic, political, and ideological problems for the young nation. The American Civil War, the Emancipation Proclamation, and the 13th Amendment to the US Constitution ended slavery in the US. With the end of slavery, ex-slaves were free to pursue work of their choosing in order to earn a living for themselves and their families. It was anticipated that as a result the economic status of ex-slaves would improve.

One important factor in the anticipated upswing in the economic status of ex-slaves would be their moving away from the South to the industrializing North. In addition, ex-slaves with Human Capital, such as being literate, would also prosper. In this paper I examined the economic status of the African American population, ex-slaves and Freedmen, from 1870 to 1920. My results indicate the following:

- Ex-slaves did not fare as well as Freedmen in the socioeconomic process. Ex-slaves had lower SEI scores and inferior jobs compared to Freedmen.

- Migrating from the South to the North has an economic payoff, but it appears that migrating from the North to the South also has an effect, and to some degree, greater than migrating from South to North. The latter result is due to the fact that Freedmen, who have more Human Capital than exslaves, were more likely to migrate from the North to the South after the Civil War.

- Being literate is a big advantage and those that were literate realized important economic returns to this Human Capital.

There are three conclusions to be drawn from my research. First, while there were important economic benefits to ex-slaves due to their emancipation, the results were not as significant compared to Freedmen. Secondly, migration improved the economic status of both ex-slaves and Freedmen, but particularly Freedmen, who migrated from North to the South after the Civil War. Finally, and perhaps most importantly, the end of slavery opened new horizons for both Freedmen and ex-slaves that they would not have realized if that "peculiar institution" had remained in place. 


\section{References}

Behrendt, S. (1999). Transatlantic Slave Trade Africana: The Encyclopedia of the African and African American Experience. New York, NY: Basic Civitas Books.

Berlin, I. (2003). Generations of Captivity: A History of African American Slaves. Cambridge, MA: Harvard University Press.

Berlin, I. (1998). ManyThousands Gone: The FirstTwo Centuries of Slavery in North America. Cambridge, Mass: Harvard University Press.

Bernstein, D. E. (1998). The Law and Economics of Post-Civil War Restrictions on Interstate Migration by African Americans. Texas Law Review. 76, pp. 781-847.

Blassingame, J. L. (1979). The Slave Community: Plantation Life in the Antebellum South. New York, NY: Oxford University Press.

Brown, T. J. (ed.). (2006). Reconstructions: New Perspectives on Postbellum America. New York, NY: Oxford University Press.

Carson, S. A. (2009). African American and White Inequality In The Nineteenth Century American South: A Biological Comparison. Journal of Population Economics. 757-772.

Case, A., Fertig, A. and Paxson, C. (2005). The Lasting Impact of Childhood Health and Circumstance. Journal of Health Economics. 24, 365-389.

Case, A., Lubortsky, D., Paxson, C. (2002). Economic Status and Health in Childhood: The Origins of the Gradient. American Economic Review. 92, 1308-1334.

Chin, G. J. (2004). The Voting Rights Act of 1867: The Constitutionality of Federal Regulation of Suffrage During Reconstruction. North Carolina Law Review. 82. http://papers.ssrn.com/s013/papers. cmf?Abstract_cd=589301.

Costa, D. L. (2005). Race and Older Age Mortality: Evidence from Union Army Veterans. NBER Working Paper No. 10902.

Costa, D. L., Kahn, M. E., (2006). Forging a New Identity: The Costs And Benefits Of Diversity In Civil War Combat Units For Black Slaves And Freedmen. Journal of Economic History. 66, 936-962.

Costa, D. L., Helmchen, L., Wilson, S. (2007). Race, Infection, and Arteriosclerosis in the Past. Proceedings of the National Academy of Sciences. 104. 13219-13224.

Davis, D. B. (2006). Inhuman Bondage: The Rise and Fall of Slavery in the New World. New York, NY: Oxford University Press.

Donald, D. H., et al. (2001). Civil War and Reconstruction. New York, NY: WW Norton and Company.

Ezell, J. S. (1963). The South Since 1865. New York, NY: Macmillan.

Fehrenbacher, D. E. (1978). The Dred Scott Case: Its Significance in American Law and Politics. New 
York, NY: Oxford University Press.

Fogel, R. W. (1994). Economic Growth, Population Theory, and Physiology: The Bearing of Long Term Processes on the Making of Economic Policy. American Economic Review. 84. 369-395.

Foner, E., Mahoney, O. (1995). America's Reconstruction: People and Politics After the Civil War. New York, NY: Harper Perennial.

Foner, E. (1988). Reconstruction: America's Unfinished Revolution, 1863-1877. New York, NY: Harper and Row.

Foner, E. (2005). Forever Free: The Story of Emancipation and Reconstruction. New York, NY: Knopf.

Foner, E. (2007). Give me Liberty!: An American History 1. Boston, Mass.: W. W. Norton and Company.

Foner, E. (2009). Give Me Liberty! London, UK: Seagul Edition.

Franklin, J. H. (1961). Reconstruction After the Civil War. Chicago, IL: University of Chicago Press.

Frost, W. J. (2008). Christianity: A Social and Cultural History. Upper Saddle River, NJ: Prentice Hall.

Genovese, E. D. (1965). The Political Economy of Slavery: Studies in the Economy and Society of the Slave South. New York, NY: Pantheon Books.

Genovese, E. D. (1974). Roll, Jordan, Roll:The World the Slaves Made. NewYork, NY: Pantheon Books.

Goldin, C. (1979). ' $N$ ' Kinds of Freedom: An Introduction to the Issues. Explorations in Economic History, 16, 8-30.

Hamilton, C. H. (1959). Educational Selectivity of Net Migration from the South. Social Forces. 38. $33 \cdot-42$.

Hesseltine, W. B. (1936). A History of the South: 1607-1936. New York, NY: Prentice Hall.

Horton, J. O. and Horton, L. E. (2005). Slavery and the Making of America. New York, NY: Oxford University Press.

Hunter, T. W. (1997). To Joy My Freedom: Southern Black Women's Lives and Labors after the Civil War. Cambridge, Mass.: Harvard University Press.

Jones, J. (2010). Labor of Love, Labor of Sorrow: Black Women, Work, and the Family from Slavery to the Present. New York, NY: Basic Books.

Kolchin, P. (1994). American Slavery: 1619-1877. New York, NY: Hill and Wang.

Leiberson, S. (1978). Selective Black Migration from the South: A Historical View. In Bean, F., Parker, W. (eds.), The Demography of Racial and Ethnic Groups. New York, NY: Academic Press.

Litwack, L. (1961). North of Slavery: The Negro in the Free States, 1790-1860. Chicago, III.: University 
of Chicago Press.

Litwack, L. (1979). Been in the Storm So Long:The Aftermath of Slavery. New York, NY: Knopf.

Margo, R. A. (1988). Schooling and the Great Migration. NBER Working Paper No. 2679.

Margo, R. A. (1990). Race and Schooling in the South, 1880-1950. Chicago: The University of Chicago Press.

Margo, R. A. (2004). The North-South Wage Gap, Before and AfterThe Civil War. In Eltis, D, Lewis, F. D., Sokoloff, K.L. (eds.) Slavery in the Development of the Americas. New York, NY: Cambridge University Press.

Mc Pherson, J. (1988). Battle Cry Freedom: The Civil War Era. New York: Oxford University Press.

Mc Pherson, J. and Hogue, J. (2009). Ordeal by Fire: The Civil War and Reconstruction. New York, NY: Mc Graw-Hill.

Noll, M. (2006). The Civil War as a Theological Crisis. Chapel Hill, NC: University of North Carolina Press.

Oakes, J. (1998). The Ruling Race: A History of American Slaveholders. New York, NY: WW Norton and Company.

Paskoff, P. (2008). Measures of War: A Quantitative Examination of the Civil War's Destructiveness in the Confederacy, Civil War History. 54. 1.

Randall, J. G. (1953). The Civil War and Reconstruction. Boston: DC Heath and Company.

Ransom, R. L. (2010). The Economics of the Civil War. http://eh.net/encyclopedia/article/ransom.civil. war.us.

Rhodes, J. G. (1920). History of the United States From the Compromise of 1850 to the McKinley-Bryan Campaigns of 1896. Vol. 6. New York, NY: Macmillan.

Schneider, C., and Schneider, D. (2007). Slavery in America. New York, NY: Infobase Publishing.

Shryock, H. S., Nam, C. (1965). Educational Selectivity in Interregional Migration. Social Forces. 43. 293-310.

Segal, D. (1995). The Black Diaspora: Five Centuries of the Black Experience Outside Africa. New York, NY: Farrar, Straus, and Giroux.

Sjaastad, L.A. (1962). The Costs and Returns of Human Migration. Journal of Political Economy. 70. 80-93.

Slave Population Data. www.fisher.lib.virginia.edu/collections/STATS/histcensus/php/newlong.php.

Stampp, K.M. (1956). The Peculiar Institution: Slavery in the Antebellum South. New York, NY: Knopf.

Stampp, K. M. (1967). The Era of Reconstruction: 1865-1877. New York, NY: Knopf. 
Steckel, R. H. (1986a). Birth Weights and Infant Mortality among American Slaves. Explorations in Economic History. 23, 173-198.

Steckel, R. H. (1986b). A Peculiar Population: The Nutrition, Health and Mortality of American Slaves from Childhood to Maturity. Journal of Economic History. 46, 57-77.

Steckel, R. H. (1986c). A Dreadful Childhood: The Excess Mortality of American Slaves. Social Science History. 10, 427-465.

Steckel, R. H. (1995). Stature and the Standard of Living. Journal of Economic Literature. 33, 19031940.

Steckel, R. H. (2004). Fluctuations in a Dreadful Childhood: Synthetic Longitudinal Height Data, Relative Prices and Weather in the Short-Term Health of American Slaves. NBER Working Paper No. 10993.

Steckel, R. H. (2007). A Pernicious Side ofCapitalism:The Care and Feeding ofSlave Children. Unpublished paper. The Ohio State University.

Tadman, M. (1989). Speculators and Slaves: Masters, Traders, and Slaves in the Old South. Madison, WI: University of Wisconsin Press.

Tolnay, S. E. (1998). Educational Selection in the Migration of Southern Blacks 1880-1990. Social Forces. 77, 487-514.

U.S. News and World Report. Nd. The First Black Americans. www.usnews.com/usnews/news/ articles/070121/29african.htm.

Wilkerson, I. (2010) The Warmth Of Other Suns: The Epic Story of America's Great Migration. New York, NY: Random House.

Woodson, C. G. (1918). A Century of Negro Migration. New York, NY: AMS Press.

\section{Endnotes}

1. Throughout this paper, I use the terms African Americans and Blacks interchangeably.

2. Research also indicates that it was the more educated Black population that migrated after the civil war (Woodson 1918; Hamilton 1959; Shryock and Nam 1965; Leiberson 1978; Margo 1988, 1990; Tolnay 1998; Bernstein 1998).

3. See Russell Menard, Trent Alexander, Jason Digman, and J. David Hacker Minneapolis: Minnesota Population Center, Public Use Microdata Samples of the Slave Population of 1850-1860, University of Minnesota, 2004.

4. The regressions are based on a Gamma distribution rather than the routine Gaussian distribution. After examining SEl distributions, it was clear that a Gamma distribution would be a better fit. In addition, I logged SEI.

* Richard R. Verdugo has a Doctorate in Sociology from the University of Southern California. His research interests are in Education, Sociology, Economics, and Demography. Recent publications include books on the Hispanic population in the United States (Information Age Publishers); forthcoming books on European Education Reform (IAP), and Latin American Immigrants in Spain (Springer); and articles on Education Reform in China, and School Quality and Economic Competitiveness (International Journal of Education Reform, which he is guest editing). Future work includes Russian Identity, the Mexican American Worker: 1900 to 2010, and research on Hegemonic Organizations and the PISA study. Richard may be reached atswamis59@yahoo.com. 